\title{
Analisis Faktor-Faktor UTAUT dan Trust Terhadap Behavioral Intention Pengguna BNI Mobile Banking Pada Pekerja Migran Indonesia
}

Rita

Universitas Bina Nusantara

rita@binus.ac.id

Mita Handra Fitria

Universitas Bina Nusantara

mitahandra@gmail.com

\begin{abstract}
The purpose of this study is to analyze the UTAUT and Trust factors on the Behavioral Intention of BNI mobile banking users on Indonesian Migrant Workers. Performance expectancy, Effort Expectancy, Social Influence, Facilitating Conditions, and Trust as independent variables, Behavioral intention as the dependent variable, and Gender and Age as moderators in this study. The sampling technique used in this study is a side probability as a sampling method. Where probability sampling in this study provides equal opportunities for each element in the population to be selected. Researchers used simple random sampling where the distribution of samples was carried out randomly within the population and each member had the same opportunity. Data collection was carried out by distributing survey questionnaires which were filled in by 100 Indonesian Migrant Workers' participants. The analysis tool used is Smart PLS 3.3.2. The results showed that Performance Expectancy, Effort Expectancy, Social Influence, Facilitating Conditions, and Trust towards the Behavioral intention of BNI Mobile banking users to Indonesian Migrant Workers simultaneously. Meanwhile, partially there is an influence on the Facilitating conditions variable on the Behavioral intention of BNI Mobile banking users for Indonesian Migrant Workers, but there is no influence on Performance expectancy, Effort Expectancy, Social Influence, and Trust on the Behavioral intention of BNI Mobile banking users for Indonesian Migrant Workers. There is no influence of the Gender and Age variables in moderating the effect of the Facilitating conditions variable on the Behavioral intention of BNI Mobile banking users to Indonesian Migrant Workers.
\end{abstract}

Keywords UTAUT, Trust, Mobile banking, Behavioral Intention.

\section{LATAR BELAKANG}

Smartphone sudah menjadi bagian dari hidup setiap individu. Layanan smartphone telah diperkenalkan diberbagai sektor termasuk pemerintah, perbankan, layanan kesehatan, dan perdagangan (Sharma, 2019). Perbankan menjadi salah satu sektor yang sudah beralih untuk 
mengembangkan layanan perbankan dengan sentuhan digital. Pergeseran konvesional kearah digital pada sektor perbankan diiringi dengan pesatnya pertumbuhan teknologi dan kebiasaan individu dalam mengandalkan smartphone. Tingginya pengguna mobile phone menjadikan kegiatan perbankan dialihkan ke layanan mobile yang dapat diakses secara langsung seperti cek saldo, transfer dana, pembayaran tagihan, dan lain-lain.

Perbankan di Indonesia mulai memperkenalkan layanan berbasis digital pertama kali yaitu internet banking pada September 1998 yang dilakukan pertama kali oleh Bank Indonesia. Internet banking sendiri mengacu pada penggunaan situs web bank dimana customer bisa mengakses akun bank mereka, melakukan transaksi keuangan, dan mendapatkan informasi umum pada produk dan layanan bank (Yu et al., 2015)). Internet banking dapat diakses melalui website bank.

Namun setelah masuknya smartphone ke Indonesia, sektor perbankan memperkenalkan kembali layanan berbasis digital yang menggunakan aplikasi mobile phone yaitu mobile banking. Dimana mobile banking adalah aplikasi m-commerce yang disampaikan oleh Lembaga keuangan atau bank yang memungkinkan pengguna dapat melakukan transaksi jarak jauh dengan mengadopsi perangkat selular seperti Personal Digital Assistants (PDA), mobile phone atau smartphone (Baabdullah et al., 2019). Kegiata transaksi dapat dilakukan dengan menginstall aplikasi pada smartphone tanpa mengunjungi Bank setiap saat hanya untuk melakukan operasi seperti cek saldo akun, transfer dana, dan pembayaran tagihan (Sangar \& Rastari, 2015). Layanan mobile banking sendiri memungkinkan pengguna dapat mengakses rekening bank mereka dan melakukan transaksi perbankan kapan saja dan dimana saja (Sharma, 2019). Selain memberikan keuntungan bagi konsumen, mobile banking juga rupanya memberikan keuntungan bagi bank karena selain dapat meningkatkan kepuasan konsumen, juga sebagai strategi dalam pengurangan modal biaya dan juga meningkatnya profitabilitas (Abadi et al., 2012)

Tingginya penggunaan mobile phone dan penggunaan internet menjadikan segala kegiatan dialihkan ke digital, termasuk sektor perbankan. Hal ini juga sudah diatur oleh Otoritas Jasa Keuangan (OJK) yang menerbitkan peraturan nomor 12/POJK.03/2018 mengenai Penyelenggaraan Layanan Perbankan Digital oleh Bank Umum atau POJK Layanan Perbankan Digital. Penerbitan peraturan tersebut dilatarbelakangi oleh semakin berkembangnya inovasi perbankan disektor teknologi informasi.

Di Indonesia sendiri hampir semua perbankan baik Bank BUMN ataupun Bank Swasta sudah mengaplikasikan mobile banking pada setiap customer mereka. Selain mempermudah kegiatan transaksi customer dalam melakukan pembayaran, customer juga dapat menghemat waktu mereka dalam melakukan transaksi. Beberapa peneliti telah mengidentifikasi manfaat dari mobile banking dalam hal cakupan apapun, fleksibilitas, interativitas, dan dengan aksesibilitas yang lebih besar dibandingkan dengan saluran perbankan konvensional seperti Automated Teller Machine (ATM) dan perbankan non-seluler lainnya (Cheah et al., 2011) 


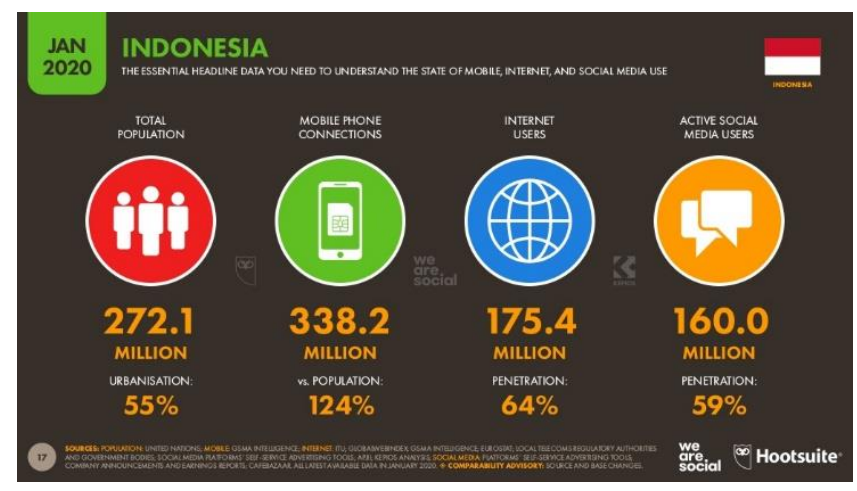

Gambar 1. Mobile Users in Indonesia

Sumber: Datareportal

Berdasarkan data infografis yang dilakukan oleh Hootsuite pada Januari 2020 total populasi di Indonesia sebanyak 272,1 Juta jiwa, sedangkan untuk pengguna mobile phone di Indonesia sebanyak 338,2 Juta. Artinya peredaraan mobile phone di Indonesia lebih banyak dari jumlah penduduk diseluruh Indonesia, yang berarti bahwa individu di Indonesia bisa memiliki lebih dari satu mobile phone. Dan untuk pengguna internet tercatat ada 175,4 Juta jiwa yang aktif menggunakan internet di Indonesia, yang berarti terdapat $64 \%$ dari total populasi Indonesia sudah menggunakan internet.

Dari data yang dipaparkan membuktikan bahwa masyarakat di Indonesia sudah bergantung dengan mobile phone dan juga internet dalam melakukan aktivitas harian mereka. Kebiasaan individu di Indonesia yang seperti ini menjadi peluang bagi pelaku bisnis di setiap sektor bisnis termasuk sektor perbankan. Peran kantor cabang perbankan pun digantikan oleh digital perbankan yang menjadikan aktivitas transaksi seperti transfer dana hanya perlu mengeluarkan mobile phone lalu masuk kedalam aplikasi dan memasukan sejumlah nominal yang diinginkan.

Survey yang dilakukan oleh Price waterhouse Coopers (PwC) pada tahun 2018 mencatat mobile banking berdasarkan aplikasi yang berbasis smartphone merupakan komponen utama dari strategi digital sektor perbankan di Indonesia. Menurut survey tersebut $86 \%$ responden memilih aplikasi mobile banking berbasis smartphone kunci dari strategi digital sektor perbankan, internet banking mengikuti erat dengan $68 \%$ dari responden yang memilih sebagai komponen strategi digital. Dan ATM mendapatkan 48\% responden menjadi hal kritis komponen strategi digital. Ini menandakan bahwa mobile banking merupakan komponen penting yang patut diperhitungkan dalam strategi jangka panjang untuk menjadikan segala aktivitas keuangan beralih ke non tunai.

Namun niat masyarakat di Indonesia masih rendah terhadap penggunaan mobile banking. Seperti survey yang dilakukan oleh Indonesia Millenial pada tahun 2019 kepemilikan produk keuangan non tunai mobile banking dengan presentase hanya sebesar 6,7\% saja, dibandingkan dengan produk keuangan non tunai lainnya. Dan kartu debit berada diperingkat pertama dengan presentase sebesar 64,2\%. Ini menunjukan bahwa kepercayaan masyarakat Indonesia terhadap penggunaan mobile banking masih kurang dibandingkan dengan produk keuangan non tunai lainnya.

Namun dibandingkan dengan layanan internet banking ternyata perkembangan mobile banking terbilang paling cepat. Ini disebabkan karena mobile banking mampu menjawab 
kebutuhan masyarakat yang mengedepankan kecepatan digital mobile. Hanya dengan sekali sentuhan pada aplikasi banking, masyarakat bisa melakukan segala aktivitas keuangan. Dengan ini mobile banking mampu menciptakan kemudahan layanan perbankan bagi para penggunanya yang terbilang cukup kompleks. Selain itu menurut Statista pada kuartal tiga 2019 pengguna internet yang menggunakan mobile apps di Indonesia dengan kategori aplikasi banking mencapai 33\%. Walaupun data menunjukan pengguna aplikasi banking lebih rendah dari pada aplikasi mobile lainnya, namun aplikasi banking masih unggul dari aplikasi seperti health and fitness ataupun dating and friendship. Besar kemungkinan bahwa pengguna aplikasi banking akan bertambah kedepannya seiring dengan perkembangan teknologi.

Penggunaan digital banking di Indonesia sendiri mengalami pertumbuhan yang signifikan menjadi 2,5 kali lipat sejak tahun 2014. OJK juga mengemukakan bahwa transaksi penggunaan digital banking meningkat 169\% dari 150,8 Juta transaksi pada 2012 menjadi 405,5 Juta transaksi pada tahun 2016. Hingga tahun 2019 aktifitas digital banking berkontribusi $32 \%$ pada populasi bank, pertumbuhan ini menjadi signifikan karena pengguna aktif secara digital dan menguntungkan sektor perbankan.

Bank Negara Indonesia atau BNI merupakan salah satu bank BUMN (Badan Usaha Milik Negara) dan termasuk bank terbesar di Indonesia. Menjadikan BNI masuk kedalam deretan lima besar bank yang mencatat pertumbuhan asset tertinggi. BNI mampu mencetak asset sebesar 845,60 Triliun dan laba bersih pada tahun 2019 senilai 15,38 Triliun. BNI memiliki berbagai macam produk digital yang mampu memudahkan BNI dalam menjangkau pelanggan, salah satunya adalah mobile banking. Jumlah nasabah mobile banking BNI terus meningkat setiap tahunnya. Berdasarkan informasi yang peneliti dapatkan dari unduhan pada playstore pengguna android, untuk BNI dengan aplikasi BNI Mobile banking memiliki unduhan yang mencapai lebih dari 5 Juta pengguna. Dan total ini belum termasuk dari pengguna mobile banking yang menggunakan smartphone berbasis IOS.

Dalam penelitian ini akan menggunakan Unified Theory of Acceptance and Use of Technology (UTAUT) untuk mengetahui niat perilaku penggunaan BNI Mobile banking pada Pekerja Migran Indonesia (PMI). UTAUT sendiri merupakan model yang sering digunakan oleh para peneliti untuk menguji niat adopsi terhadap IT/IS terbaru (Madan, K. \& Yadav, 2016). Selain itu, UTAUT memiliki empat konstruk utama untuk memeriksa atau memprediksi penggunaan IT/IS dalam konteks organisasi yaitu, performance expectancy (PE), Effort expectancy (EE), Social influence (SI), dan Facilitating conditions (FC) (Paulo et al., 2018). Peneliti juga akan menambahkan variable tambahan untuk melengkapi permasalahan penelitian yang sedang peneliti teliti yaitu, variable Trust. Dimana Trust sendiri mendukung dalam menanamkan kepercayaan pengguna atau pelanggan baru dalam menggunakan BNI Mobile banking baik itu dari kepercayaan terhadap bank, kepercayaan terhadap internet, ataupun kepercayaan terhadap informasi mobile banking (Kwateng et al., 2019).

\section{LANDASAN TEORI}

\section{Unified Theory of Acceptance and Use of Technology (UTAUT)}

Unified Theory of Acceptane and Use of Technology (UTAUT) diperkenalkan oleh Venkatesh, Morris, Davis, dan Davis (2003) dan berfungsi sebagai model teoritis menyeluruh dalam penelitian penggunaan suatu teknologi (Rahi \& Ghani, 2018). Venkatesh et al. (2003) meninjau literatur penerimaan penggunaan IT dan membahas delapan model penerimaan yang menonjol, yaitu : Theory of Reasoned Action (TRA), Technology Acceptance Model (TAM), T 
Motivational Model, T Theory of Planned Behavior (TPB), T Combined TAM and TPB (CTAM-TPB), T Model of PC Utilization (MPCU), T Innovation Diffusion Theory (IDT), dan $T$ Social Coginitive Theory (Yaseen \& El Qirem, 2018). Berdasarkan delapan model penerimaan tersebut Venkatesh et al (2003) menemukan Unified Theory of the Acceptance and Use of Technology (UTAUT) sebagai suatu model penerimaan teknologi yang baru (Yaseen \& El Qirem, 2018). Venkatesh et al. (2003) juga mengkaji dan mensintesiskan delapan teori / model penggunaan teknologi tersebut ke dalam teori Unified Theory of Acceptance and Use of Technology (UTAUT) untuk mengintegrasikan teori dan penelitian terfragmentasi mengenai penerimaan teknologi informasi kedalam model teori terpadu (Nair et al., 2015). Unified Theory of the Acceptance and Use of Technology (UTAUT) sendiri hasil dari kombinasi delapan teori / model teknologi penerimaan yang diambil dari empat konstruksi yaitu performance expectancy, effort expectancy, social influence, dan facilitating conditionss dan dimoderasi oleh jenis kelamin, usia, pengalaman, dan kesukarelaan penggunaan (Paulo et al., 2018). Unified Theory of the Acceptance and Use of Technology (UTAUT) sendiri dipilih karena menunjukkan penjelasan yang sangat kuat pada niat individu dalam menerima suatu teknologi informasi (IT), serta cocok untuk menjelaskan dan memprediksi perilaku seseorang terkait dengan penggunaan system informasi (SI) berlanjut (C.-G. $\mathrm{Wu} \& \mathrm{Wu}, 2019$ ). Dibandingkan dengan penelitian model sebelumnya, Unified Theory of the Acceptance and Use of Technology (UTAUT) memiliki 70\% lebih jelas untuk keputusan penerimaan teknologi, UTAUT mewakili rangkaian konstruksi yang lebih lengkap untuk menjelaskan dan memprediksi perilaku pengguna (Shih et al., 2018).

\section{Trust}

Kepercayaan (trust) adalah factor kunci dan fondasi dalam mengembangkan bisnis dalam transaksi online (Khatimah \& Halim, 2014). Kepercayaan (trust) didefinisikan sebagai kesediaan individu untuk setia kepada penyedia layanan berdasarkan ekspektasi positif terhadap perilaku penyedia layanan di masa depan (Roy et al., 2018). Kepercayaan (trust) mencakup tiga hal, yaitu: kemampuan, integritas, dan kebijakan (Zhou, 2012). Dimana dijelaskan bahwa kemampuan berarti penyedia layanan memiliki pengetahuan dan kemampuan yang diperlukan untuk memenuhi standar kerja mereka. Integritas berarti bahwa penyedia layanan mampu memenuhi janji mereka dan tidak menipu pengguna. Sedangkan kebijakan berarti bahwa penyedia layanan memperhatikan kepentingan pengguna, bukan hanya mendapatkan keuntungan sendiri. Kepercayaan (trust) berarti ekspektasi subjektif bahwa seseorang atau sesuatu dapat diandalkan dan bersedia menerima ketentanan (Tarhini et al., 2017). Kepercayaan (trust) sendiri merupakan penentu mendasar yang mempengaruhi perilaku pengguna dan perilaku niat (behavioral intention) untuk mengadopsi layanan elektronik.

\section{Behavioral Intention}

Dalam penelitian penerimaan suatu teknologi baru selalu berhubungan dengan konsep perilaku penggunaan teknologi tersebut. Model penerimaan (acceptance model) suatu teknologi sebenarnya berdasarkan asumsi bahwa niat perilaku (behavioral intention) merupakan prediksi yang valid dari perilaku penggunaan yang sebenarnya; banyak studi empiris yang berfokus pada menjelaskan niat perilaku (behavioral intention) karena mereka memiliki hubungan antara niat dan penggunaan perilaku (Agudo-Peregrina et al., 2014). Menurut Li (2012) niat perilaku (behavioral intention) berperan sebagai penentu secara langsung dan predictor perilaku terbaik. Beberapa model psikologi social secara eksplisit menghipotesiskan bahwa 
niat perilaku (behavioral intention) menjadi penentu langsung perilaku, termasuk teori tindakan beralasan, perilaku yang direncanakan (planned behavior), motivasi perlindungan (protection motivation), perilaku interpersonal (interpersonal behavior) (J. Wu \& Du, 2012). Niat perilaku (behavioral intention) merupakan keinginan individu dalam mengadopsi teknologi baru (Raza et al., 2019). Niat individu untuk menggunakan suatu teknologi sangatlah bervariasi dan semua tergantung dari fitur-fitur yang ditawarkan oleh teknologi tersebut. Niat perilaku (behavioral intention) juga didefinisikan sebagai persepsi kemungkinan individu memanfaatkan sesuatu dalam situasi tertentu (Kwateng et al., 2019). Selain itu, niat perilaku (behavioral intention) bergerak sebagai perantara hubungan antara variable perilaku dan bagaimana mengimplementasikan perilaku sebenarnya itu sendiri, sehingga dari situ tindakan individu bisa diramalkan di masa depan secara akurat (Farah et al., 2018)

\section{METODE PENELITIAN}

Pada penelitian ini menggunakan tipe desain penelitian survey dimana penelitian ini bersifat kuantitatif untuk meneliti perilaku individu atau kelompok. Metode pengumpulan data yang digunakan dalam penelitian ini adalah survey kuesioner. Survey dilakukan dengan menyebarkan kuesioner kepada pekerja migran Indonesia (PMI) yang berada di tempat Pembekalan Akhir Pemberangkatan (PAP) dimana tempat ini merupakan tempat para Pekerja Migran Indonesia (PMI) mendapatkan edukasi kuangan dari staff marketing BNI Remittance sebelum berangkat ke negara tujuan mereka untuk bekerja. Teknik pengambilan sampel yang digunakan dalam penelitian ini adalah probability samping sebgai metode sampling. Dimana probability sampling pada penelitian ini memberikan peluang yang sama bagi setiap elemen didalam populasi untuk terpilih. Peneliti menggunakan simple random sampling yang penyebaran sampel dilakukan secara acak didalam populasi dan setiap anggota memiliki kesempatan yang sama. Sedangkan time horizon yang digunakan dalam penelitian ini adalah cross sectional dimana informasi atau sampel yang diambil hanya dalam jangka waktu tertentu. Teknik pengumpulan data pada kuesioner di penelitian ini adalah dengan menyebarkan kuesioner melalui link google form ditempat Pembekalan Akhir Pemberangkatan (PAP) serta data yang didapatkan akan dijadikan sebagai sumber data dalam penelitian. Target responden yang akan mengisi kuesioner ini adalah para pekerja migran Indonesia (PMI) yang akan berangkat ke negara tujuan mereka untuk bekerja. Populasi didalam penelitian ini adalah Pekerja Migran Indonesia (PMI) yang berada di Pembekalan Akhir Pemberangkatan (PAP). Dari data perusahaan yang peneliti dapatkan populasi pekerja migran Indonesia (PMI) yang sudah melakukan pembukaan rekening dan penggunaan mobile banking dari 2017-2019 memiliki total 116.921. Dalam menentukan jumlah sample, peneliti akan menggunakan pendekatan rumus Slovin, didapat jumlah sampel 100 responden. Dalam penelitian ini, metode analisis yang akan digunakan yaitu SEM - PLS atau metode Partial Least Square - Structural Equation Modeling, yang pengolahan datanya menggunakan software SmartPLS versi 3.0.. Berikut gambar kerangka fikir dalam penelitian ini. 


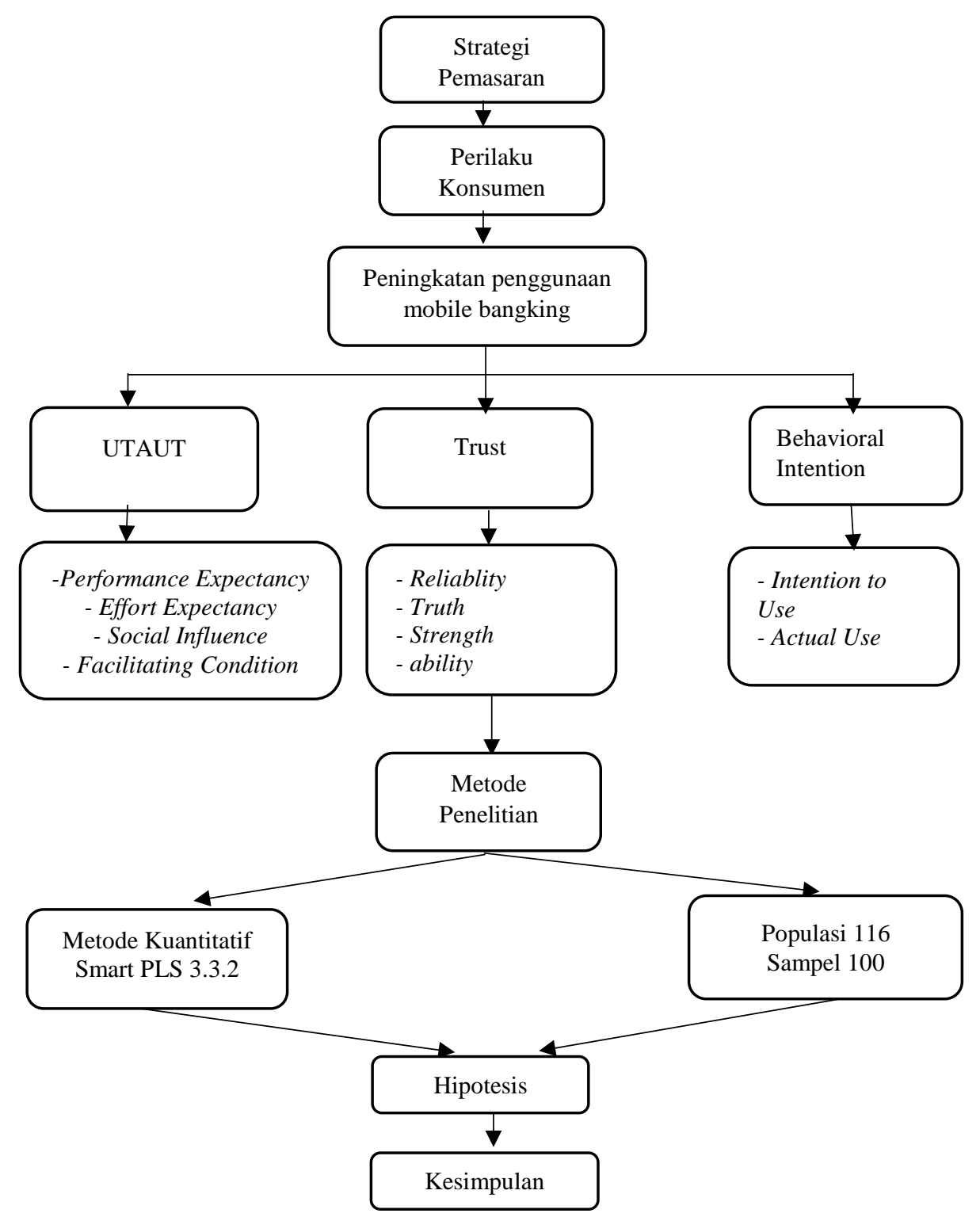

Gambar 1. Kerangka Fikir

\section{HASIL DAN PEMBAHASAN}

\section{Evaluasi Model Pengukuran (Inner Model )}

Dalam penelitian ini, peneliti menggunakan pedeketan bootstrapping untuk mencari signifikansi antar variabel. Analisis pengaruh variabel performance expectancy, effort expectancy, social influence, facilitating conditions dan trust terhadap behavioral intention secara simultan. R-Squares digunakan untuk menjelaskan pengaruh variabel UTAUT (Performance expectancy, Effort expectancy, Social influence, Facilitating conditions) dan Trust terhadap Behavioral intention penggunaan BNI Mobile banking pada Pekerja Migran Indonesia (PMI). 
Keterangan: $\mathrm{PE}=$ Performance Expectancy, $\mathrm{EE}=$ Effort Expectancy, $\mathrm{SI}=$ Social Influence, $\mathrm{FC}$ $=$ Facilitating conditions, $\mathrm{T}=$ Trust, $\mathrm{BI}=$ Behavioral Intention .

Tabel 1 Hasil R-Squares variabel performance expectancy, effort expectancy, social influence, facilitating conditions dan trust terhadap behavioral intention

\begin{tabular}{llllll}
\hline & $\begin{array}{l}\text { Original } \\
\text { Sample } \\
(\mathbf{O})\end{array}$ & $\begin{array}{l}\text { Sample } \\
\text { Mean }(\mathbf{M})\end{array}$ & $\begin{array}{l}\text { Standard } \\
\text { Deviation } \\
\text { (STDEV) }\end{array}$ & T Statistics & p Values \\
\hline PE, EE, SI, FC, T & 0,865 & 0,862 & 0,033 & 25,983 & 0,000 \\
=> BI & & & & &
\end{tabular}

Sumber: Hasil Pengolahan Data Peneliti (2020)

Dari hasil pengolahan data diatas, dapat disimpulkan bahwa variabel Performance Expectancy, Effort Expectancy, Social Influence, Facilitating conditions, dan Trust memiliki pengaruh terhadap Behavioral Intention. Maka dapat diintrepretasikan bahwa variabel Behavioral intention dijelaskan sebagai variabel konstruk Performance expectancy, Effort expectancy, Social influence, Facilitiating condition, dan Trust sebesar $86,5 \%$ sedangkan sisanya sebesar $13,5 \%$ dijelaskan oleh faktor lain diluar penelitian.

Analisis pengaruh variabel Perfrormance expectancy, Effort expectancy, Social influence, Facilitating conditions, dan Trust terhadap Behavioral intention secara parsial

Pada analisis penelitian ini akan digunakan Tvalue sebesar 1,96 dengan tingkat kesalahan sebesar 5\% (0,05). Berikut hasil dari pengujian hipotesis analisis menggunakan SmartPLS 3.32 dilihat dari path coefficient hasil dari calculate bootstraping, sebagai berikut:

Tabel 2. Hasil Path Coefficient variabel performance expectancy, effort expectancy, social influence, facilitating conditions, dan trust terhadap behavioral intention

\begin{tabular}{lllllll}
\hline & $\begin{array}{l}\text { Original } \\
\text { Sample }(\mathbf{O})\end{array}$ & $\begin{array}{l}\text { Sample } \\
(\mathbf{M})\end{array}$ & Mean & $\begin{array}{l}\text { Standard Deviation } \\
\text { (STDEV) }\end{array}$ & $\begin{array}{l}\text { T } \\
\text { Statistics }\end{array}$ & p Values \\
\hline PE => BI & $-0,026$ & $-0,010$ & 0,081 & 0,315 & 0,753 \\
\hline EE => BI & 0,101 & 0,104 & 0,094 & 1,078 & 0,282 \\
\hline SI => BI & 0,076 & 0,097 & 0,063 & 1,204 & 0,229 \\
\hline FC => BI & 0,500 & 0,412 & 0,213 & 2,353 & 0,019 \\
\hline T => BI & 0,317 & 0,365 & 0,168 & 1,887 & 0,060 \\
\hline
\end{tabular}

Sumber: Hasil Pengolahan Data Peneliti (2020)

Keterangan: $\mathrm{PE}=$ Performance Expectancy, $\mathrm{EE}=$ Effort Expectancy, $\mathrm{SI}=$ Social Influence, $\mathrm{FC}$ $=$ Facilitating Conditon, $\mathrm{T}=$ Trust, $\mathrm{BI}=$ Behavioral Intention .

Dari hasil pengolahan data, yang merupakan pengaruh variabel Performance Expectancy, Effort Expectancy, Social Influence, Facilitating conditions, dan Trust terhadap Behavioral 
Intention pengguna BNI Mobile banking secara parsial. Dapat disimpulkan bahwa Performance Expectancy, Effort Expectancy, Social Influence, dan Trust tidak memiliki pengaruh terhadap Behavioral Intention penggunaan BNI Mobile banking pada Pekerja Migran Indonesia. Namun Facilitating conditions memiliki pengaruh terhadap penggunaan BNI Mobile banking pada Pekerja Migran Indonesia. Maka untuk penelitian selanjutnya, peneliti hanya akan menggunakan variabel Facilitating conditions untuk mengetahui pengaruh terhadap Behavioral Intention dengan dimoderasi oleh Gender dan Age.

Analisis Pengaruh Variabel Gender dalam Memoderasi Pengaruh Facilitating conditions terhadap Behavioral Intention

Pada penelitian analisis ini, akan digunakan Tvalue 1,96 dengan tingkat kesalahan sebesar 5\%. Berikut hasil dari pengujian hipotesis analisis menggunakan SmartPLS 3.3.2 dengan melihat dari path coefficient hasil dari calculate bootstrapping, sebagai berikut :

Tabel 3. Hasil Path Coefficient Variabel Moderator Gender

\begin{tabular}{|c|c|c|c|c|c|}
\hline $\begin{array}{l}\text { Pengaruh } \\
\text { Variabel Gender }\end{array}$ & $\begin{array}{l}\text { Original } \\
\text { Sample } \\
\text { (O) }\end{array}$ & $\begin{array}{l}\text { Sample } \\
\text { Mean } \\
(\mathrm{M})\end{array}$ & $\begin{array}{l}\text { Standard } \\
\text { Deviation } \\
\text { (STDEV) }\end{array}$ & $\begin{array}{l}\mathbf{T} \\
\text { Statistics }\end{array}$ & $\begin{array}{l}\mathbf{p} \\
\text { Values }\end{array}$ \\
\hline $\begin{array}{l}\text { Facilitating conditions }=> \\
\text { Behavioral Intention }\end{array}$ & $-0,011$ & 0,042 & 0,103 & 0,102 & 0,919 \\
\hline
\end{tabular}

Sumber: Hasil Pengolahann Data Penelitian (2020)

Variabel Gender tidak memoderasi pengaruh Facilitating conditions terhadap pengguna BNI Mobile banking pada Pekerja Migran Indonesia.

Analisis Pengaruh Variabel Age dalam Memoderasi Pengaruh Facilitating conditions terhadap Behavioral Intention

Pada analisis penelitian ini digunakannya Tvalue sebesar 1,96 dengan level signifikan sebesar $5 \%(0,05)$. Berikut hasil dari pengujian hipotesis analisis yang dapat dilihat dari Path Coefficient hasil dari calculate bootstrapping, sebagai berikut:

Tabel 4. Hasil Path Coefficient Variabel Moderator Age

\begin{tabular}{|c|c|c|c|c|c|}
\hline $\begin{array}{l}\text { Pengaruh Moderasi } \\
\text { Variabel Age }\end{array}$ & $\begin{array}{l}\text { Original } \\
\text { Sample }(\mathbf{O})\end{array}$ & $\begin{array}{l}\text { Sample } \\
\text { Mean }(\mathrm{M})\end{array}$ & $\begin{array}{l}\text { Standard } \\
\text { Deviation } \\
\text { (STDEV) }\end{array}$ & $\begin{array}{l}\mathbf{T} \\
\text { Statistics }\end{array}$ & $\begin{array}{l}\mathbf{p} \\
\text { Values }\end{array}$ \\
\hline $\begin{array}{l}\text { Facilitating conditions } \\
=>\text { Behavioral Intention }\end{array}$ & $-0,051$ & $-0,044$ & 0,065 & 0,793 & 0,428 \\
\hline
\end{tabular}

Sumber: Hasil Pengolahan Data Peneliti (2020)

Variabel Age tidak memoderasi pengaruh Facilitating conditions terhadap pengguna BNI Mobile banking pada Pekerja Migran Indonesia. 


\section{Implikasi Hasil Penelitian Pengaruh Performance expectancy, Effort expectancy, Social influence, Facilitating conditions, dan Trust terhadap Behavioral Intention secara Simultan dan Parsial}

Hasil penelitian pengaruh variabel Performance expectancy, Effort expectancy, Social influcen, Facilitating conditions, dan Trust terhadap Behavioral intention secara simultan menunjukkan bahwa adanya pengaruh terhadap pengguna BNI Mobile banking pada Pekerja Migran Indonesia dengan tingkat pengaruh sebesar 86,5\%. Namun secara parsial, Behavioral intention tidak dipengaruhi oleh semua variabel. Melainkan hanya dipengaruhi oleh satu variabel yaitu Facilitating conditions.

Facilitating conditions mempengaruhi Behavioral intention pengguna BNI Mobile banking pada Pekerja Migran Indonesia. Hasil dari penelitian ini sejalan dengan penelitian sebelumnya yang dilakukan oleh Raza (2019) yang diberi judul Acceptance of mobile banking in Islamic banks: evidence from modified UTAUT model. Penelitian dinyatakan sejalan ditunjukkan pada variabel Facilitating conditions memiliki pengaruh terhadap Behavioral intention, namun berbeda pada variabel Performance expectancy serta Effort expectancy yang memiliki pengaruh terhadap Behavioral intention. Penelitian ini juga sejalan dengan penelitian sebelumnya yang dilakukan oleh Arshad (2018) yang diberi judul Determinants of Intention to Use Mobile banking in the North of Jordan: Extending UTAUT2 with Mass Media and Trust. Penelitian dinyatakan sejalan dilihat dari Facilitating conditions memiliki pengaruh terhadap Behavioral intention, namun berbeda pada variabel Performance expectancy, Effort expectancy, dan Social influence yang memiliki pengaruh terhadap Behavioral intention. Selain itu, Penelitian ini juga sejalan dengan penelitian sebelumnya yang dilakukan oleh Nawaz (2020) yang diberi judul Islamic banking customers intention to use mobile banking services: A Sri Lankan study. Penelitian dinyatakan sejalan yang ditujukan pada variabel Facilitating conditions memiliki pengaruh terhadap Behavioral intention, namun berbeda pada variabel Performance expectancy, Effort expectancy, dan Social influence yang memiliki pengaruh terhadap Behavioral intention pada penelitian tersebut. Hal ini menunjukkan bahwa fasilitas pendukung yang disediakan oleh BNI mampu mempengaruhi niat perilaku penggunaan BNI mobile banking pada Pekerja Migran Indonesia dalam bertransaksi menggunakan BNI Mobile banking.

Berdasarkan hasil wawancara yang peneliti lakukan dengan Staff pemasaran BNI Remittance bahwa BNI menyediakan fasilitas pelayanan bagi para Pekerja Migran Indonesia dalam membuka rekening dan pembuatan mobile banking dan memberikan pengetahuan dasar keuangan yang dilakukan secara offline, serta staff pemasaran yang selalu sedia merespon keluhan dan pembukaan rekening para Pekerja Migran Indonesia walaupun mereka sudah berada di luar negeri yang dilakukan secara online. Dari hasil wawancara tersebut, BNI Divisi Internasional, Kelompok Bisnis Remittance perlu memisahkan bagian pemasaran dengan customer service khusus untuk Pekerja Migran Indonesia, dengan menyediakan layanan customer service melalui fitur aplikasi Whatsapp Messanger. Sehingga, para Pekerja Migran Indonesia yang sudah berada diluar negeri tidak perlu mengeluarkan dana yang banyak hanya untuk menyampaikan keluhan dan pembukaan rekening atau pembuatan mobile banking dengan menghubungi domestic.

Performance expectancy tidak mempengaruhi Behavioral intention penggguna BNI mobile banking pada Pekerja Migran Indonesia. Hasil penelitian ini berbeda dengan penelitian sebelumnya yang dilakukan oleh Nawaz (2020) yang berjudul Islamic banking customers 
intention to use mobile banking services: A Sri Lanka Study. Namun penelitian ini sejalan dengan penelitian sebelumnya yang dilakukan oleh Kwateng (2019) yang berjudul Acceptance and use of mobile banking: an application of UTAUT2. Ekspekatsi kinerja (Performance expectancy) merupakan sejauh mana pelanggan atau pengguna merasa bahwa menggunakan teknologi tersebut memberikan manfaat bagi mereka. Para Pekerja Migran Indonesia yakin bahwa menggunakan BNI mobile banking bisa menghemat waktu dan meningkatkan kinerja transaksi keuangan mereka. Hal ini menunjukkan bahwa penggunaan BNI mobile banking bagi para Pekerja Migran Indonesia tidak meningkatkan kinerja transaksi keuangan mereka, dimana BNI mobile banking tidak memberikan kemudahan akses dimana saja saat bertransaksi.

Effort expectancy tidak mempengaruhi Behavioral intention pengguna BNI mobile banking pada Pekerja Migran Indonesia. Hasil penelitian ini berbeda dengan penelitian sebelumnya yang dilakukan oleh Bhatiasevi (2016)) yang berjudul An extended UTAUT model to explain the adoption of mobile banking. Namun penelitian ini sejalan dengan penelitian yang dilakukan oleh Kwateng (2019) berjudul Acceptance and use of mobile banking: an application of UTAUT2. Ekspektasi usaha (Effort expectancy) merupakan tingkat kemudahan yang dirasakan oleh konsumen atau pengguna saat menggunakan suatu teknologi. Para pekerja Migran Indonesia bisa dengan mudah menggunakan BNI mobile banking untuk melakukan transaksi. Hal ini menunjukkan bahwa penggunaan BNI mobile banking bagi para Pekerja Migran Indonesia tidak mudah saat pengoperasian aplikasi, dimana BNI mobile banking memerlukan usaha saat ingin bertransaksi.

Social influence tidak mempengaruhi Behavioral intention pengguna BNI mobile banking pada Pekerja Migran Indonesia. Hasil penelitian ini berbeda dengan penelitian sebelumnya yang dilakukan oleh Farah (2018) berjudul Mobile banking adoption: empirical evidence from the banking sektor in Pakistan. Namun, penelitian ini sejalan dengan penelitian yang dilakukan oleh Kwateng (2019) yang berjudul Acceptance and use of mobile banking: an application of UTAUT2. Pengaruh social (Social influence) merupakan keputusan konsumen dipengaruhi oleh review dari orang-orang terdekat seperti keluarga, teman, rekan kerja, dan juga pengguna teknologi lainnya. Penggunaan BNI mobile banking pada Pekerja Migran Indonesia bisa saja dipengaruhi oleh orang-orang terdekat dan staff pemasaran BNI Remittance. Hal ini menunjukkan bahwa orang terdekat tidak mempengaruhi para Pekerja Migran Indonesia dalam penggunaan BNI mobile banking.

Trust tidak mempengaruhi Behavioral intention pengguna BNI mobile banking pada Pekerja Migran Indonesia. Hasil penelitian ini berbeda dengan penelitian sebelumnya yang dilakukan oleh Arshad (2018) yang berjudul Determinants of intention to use mobile banking in the North of Jordan: Extending UTAUT2 with mass media and trust. Namun, penelitian ini sejalan dengan penelitian sebelumnya yang dilakukan oleh Farah (2018) berjudul mobile banking adoption: empirical evidence from the banking sektor in Pakistan. Kepercayaan (trust) merupakan kesukarelaan pelanggan untuk setia kepada penyedia layanan berdasarkan ekspektasi yang positif terhadap perusahaan. Para Pekerja Migran Indonesia sukarela setia dengan BNI atas ekspektasi psositif yang diberikan oleh BNI. Hal ini menunjukkan bahwa para Pekerja Migran Indonesia belum mempercayai bahwa BNI mobile banking memiliki kekuatan dalam memenuhi kebutuhan transaksi pengguna.

\section{Implikasi Hasil Penelitian Gender dan Age Memoderasi Pengaruh Facilitating conditions terhadap Behavioral Intention}


Hasil dari penelitian ini tidak menunjukkan adanya pengaruh terhadap Gender dan Age dalam memoderasi pengaruh Facilitating conditions terhadap Behavioral Intention. Gender tidak memoderasi pengaruh facilitating conditions terhadap behavioral intention. Hasil penelitian ini berbeda dengan penelitian sebelumnya oleh Kwateng (2019) yang berjudul Acceptance and use of mobile banking: an application of UTAUT2. Hal ini menunjukkan bahwa jenis kelamin tidak memoderasi facilitating conditions terhadap behavioral intention pengguna BNI mobile banking pada Pekerja Migran Indonesia. Padahal data yang diberikan oleh BNP2TKI menunjukkan gender wanita lebih banyak dibandingkan pria yang bekerja sebagai Pekerja Migran Indonesia, pada tahun 2019 gender wanita memiliki total sebanyak 191.237 orang, sedangkan pria hanya sebanyak 85.316 orang (bp2mi.go.id, 2020). Data inipun didukung oleh populasi pada survey yang dilakukan oleh peneliti dengan total populasi wanita sebesar 73,6\% dan pria 26,4\%. Hal ini menunjukkan bahwa pekerja Migran Indonesia dengan gender wanita lebih banyak menggunakan BNI mobile banking dibandingkan pria.

Age tidak memoderasi pengaruh facilitating conditions terhadap behavioral intention. Hasil penelitian ini berbeda dengan penelitian sebelumnya oleh Nawaz (2020) yang berjudul Islamic banking customers intention to use mobile banking services: A Sri Lankan study. Namun sejalan dengan penelitian sebelumnya yang dilakukan oleh Kwateng (2019) yang berjudul Acceptance and use of mobile banking: an application of UTAUT2. Hal ini menunjukkan usia tidak memoderasi facilitating conditions terhadap behavioral intention pengguna BNI mobile banking pada Pekerja Migran Indonesia. Padahal, penelitian yang telah dilakukan oleh Utami (2012) yang berjudul pengambilan keputusan bermigrasi pekerja migran perempuan menunjukkan bahwa Usia para Pekerja Migran Indonesia di dominasi pada usia 20-35 tahun. Hal inipun sesuai dengan survey yang dilakukan oleh peneli dimana usia 20-24 tahun dengan 29,2\%, usia 25-29 tahun dengan 26,4\%, dan 30-34 tahun dengan 17,9\%, yang ditotal menjadi 73,5\%. Sedangkan usia 35-39 dengan 9,4\%, usia 40-44 tahun dengan 13,2\%, dan usia 45-49 tahun dengan 3,8\%, yang ditotal menjadi 26,5\%. Hal ini menunjukkan bahwa Pekerja Migran Indonesia yang menggunakan BNI mobile banking di dominasi oleh usia 2034 tahun.

\section{KESIMPULAN}

Berdasarkan hasil penelitian yang telah dilakukan, maka dapat ditarik kesimpulannya bahwa terdapat pengaruh Performance expectancy, Effort expectancy, Social influence, Facilitating conditions, dan Trust terhadap Behavioral intention pengguna BNI Mobile banking pada Pekerja Migran Indonesia secara simultan. Sedangkan, secara parsial terdapat pengaruh pada variabel Facilitating conditions terhadap Behavioral intention pengguna BNI Mobile banking pada Pekerja Migran Indonesia, namun tidak terdapat pengaruh Performance expectancy, Effort expectancy, Social influence, dan Trust terhadap Behavioral intention pengguna BNI Mobile banking pada Pekerja Migran Indonesia. Tidak terdapat pengaruh variabel Gender dan Age dalam memoderasi pengaruh dari variabel Facilitating conditions terhadap Behavioral intention pengguna BNI Mobile banking pada Pekerja Migran Indonesia. 


\section{DAFTAR PUSTAKA}

Abadi, H. R. D., Ranjbarian, B., \& Zade, F. K. (2012). Investigate the customers' behavioral intention to use mobile banking based on TPB, TAM and perceived risk (a case study in Meli Bank). International Journal of Academic Research in Business and Social Sciences, 2(10), 312.

Agudo-Peregrina, Á. F., Hernández-García, Á., \& Pascual-Miguel, F. J. (2014). Behavioral intention, use behavior and the acceptance of electronic learning systems: Differences between higher education and lifelong learning. Computers in Human Behavior, 34, 301314.

Baabdullah, A. M., Alalwan, A. A., Rana, N. P., Kizgin, H., \& Patil, P. (2019). Consumer use of mobile banking (M-Banking) in Saudi Arabia: Towards an integrated model. International Journal of Information Management, 44, 38-52.

Cheah, C. M., Teo, A. C., Sim, J. J., Oon, K. H., \& Tan, B. I. (2011). Factors affecting Malaysian mobile banking adoption: An empirical analysis. International Journal of Network and Mobile Technologies, 2(3), 149-160.

Farah, M. F., Hasni, M. J. S., \& Abbas, A. K. (2018). Mobile-banking adoption.

Khatimah, H., \& Halim, F. (2014). Consumers' intention to use e-money in Indonesia based on Unified Theory of Acceptance and Use of Technology (UTAUT). American-Eurasian Journal of Sustainable Agriculture, 8(12), 34-40.

Kwateng, K. O., Atiemo, K. A. O., \& Appiah, C. (2019). Acceptance and use of mobile banking: an application of UTAUT2. Journal of Enterprise Information Management.

Li, M., \& Cai, L. A. (2012). The effects of personal values on travel motivation and behavioral intention. Journal of Travel Research, 51(4), 473-487.

Nair, P. K., Ali, F., \& Leong, L. C. (2015). Factors affecting acceptance \& use of ReWIND. Interactive Technology and Smart Education.

Paulo, M. M., Rita, P., Oliveira, T., \& Moro, S. (2018). Understanding mobile augmented reality adoption in a consumer context. Journal of Hospitality and Tourism Technology.

Rahi, S., \& Ghani, M. A. (2018). The role of UTAUT, DOI, perceived technology security and game elements in internet banking adoption. World Journal of Science, Technology and Sustainable Development.

Raza, S. A., Shah, N., \& Ali, M. (2019). Acceptance of mobile banking in Islamic banks: evidence from modified UTAUT model. Journal of Islamic Marketing.

Roy, S. K., Balaji, M. S., Soutar, G., Lassar, W. M., \& Roy, R. (2018). Customer engagement behavior in individualistic and collectivistic markets. Journal of Business Research, 86(October 2016), 281-290. https://doi.org/10.1016/j.jbusres.2017.06.001

Sangar, A. B., \& Rastari, S. (2015). A model for increasing usability of mobile banking apps on smart phones. Indian Journal of Science and Technology, 8(30), 1-9. 
Sharma, S. K. (2019). Integrating cognitive antecedents into TAM to explain mobile banking behavioral intention: A SEM-neural network modeling. Information Systems Frontiers, $21(4), 815-827$.

Shih, P.-H., Yang, K.-C., \& Yang, C. (2018). The link between state-of-mind and individuals' willingness to adopt and continue using smartphones. Kybernetes.

Tarhini, A., Al-Busaidi, K. A., Mohammed, A. B., \& Maqableh, M. (2017). Factors influencing students' adoption of e-learning: a structural equation modeling approach. Journal of International Education in Business.

Utami, R. T., \& Sukamdi, S. (2012). Pengambilan Keputusan Bermigrasi Pekerja Migran Perempuan (Kasus di Desa Jangkaran, Kecamatan Temon Kabupaten Kulon Progo). Jurnal Bumi Indonesia, 1(1).

Wu, C.-G., \& Wu, P.-Y. (2019). Investigating user continuance intention toward library selfservice technology. Library Hi Tech.

Wu, J., \& Du, H. (2012). Toward a better understanding of behavioral intention and system usage constructs. European Journal of Information Systems, 21(6), 680-698.

Yaseen, S. G., \& El Qirem, I. A. (2018). Intention to use e-banking services in the Jordanian commercial banks. International Journal of Bank Marketing.

Yu, P. L., Balaji, M. S., \& Khong, K. W. (2015). Building trust in internet banking: a trustworthiness perspective. Industrial Management \& Data Systems.

Zhou, T. (2012). Understanding users' initial trust in mobile banking: An elaboration likelihood perspective. Computers in Human Behavior, 28(4), 1518-1525. 